\title{
THE IMPORTANCE OF INTERNAL HEAT GAINS FOR BUILDING COOLING DESIGN
}

\author{
Turgay Coşkun ${ }^{1, *}$, Cihan Turhan², Zeynep Durmuş Arsan³, Gülden Gökçen Akkurt² \\ Keywords: Internal Heat Gains, Cooling Load; Dynamic Simulation
}

\begin{abstract}
This paper aims to investigate the effect of internal heat gains on the cooling load of a building. The house occupied by three adult men is selected as the case study for paper. The house is in the third floor of the apartment. The apartment has four flats and it has no insulation around the external walls. The heat dissipation from lighting devices, electrical equipment and the occupants are calculated by using the DesignBuilder v4 Beta release simulation program. The temperature of the house is observed during three weeks by using hobo data loggers and calibration of the measurements is made with respect to weather data file of the flat. Detailed schedule based on time of operation and occupancy is prepared to get more accurate results. Annual energy consumption and cooling load of the house is determined by using the dynamic simulation program.
\end{abstract}

\section{INTRODUCTION}

The internal load of a building can be calculated correctly, if all of the sources of internal heat gains are taken into account. The main sources of internal loads are occupants, lighting devices and electrical equipment. The determination of cooling load of a building depends on heat gains in a building energy model [1].

One of the internal loads, the internal metabolic rate in the human body, is the main source of latent and sensible heat gains of the building which depends on the activity. Tarik El-Shemmeri [2] defined typical heat emission from the people with respect to activity. He assumed that an adult man spreads $80 \mathrm{~W}$ when sleeping and $570 \mathrm{~W}$ when doing heavy work, respectively. The metabolic rate also depends on the sexuality and age of the human.

Any change in occupancy of the building is not a way to increase the energy efficiency of the building. Martani et al. [3] studied on the dynamic relationship between building occupancy and energy consumption. He measured the occupancy of an office building by using Wi-Fi connections. By this way, the running time and capacity of heating and ventilation system in the office was changed with respect to the occupancy.

Lighting devices is a source of convectional and radiant heat gains in the building. There is some possible ways to decrease cooling load of the building by changing the lighting type. The LED lighting has the potential to provide energy savings. And in many countries, there are policies to encourage its use owing to its higher efficiency and longer life in comparison to other lighting fixtures. However, since $75-85 \%$ of the light electric power in LED lights is still generated as heat, the sole use of LED lighting in a building could have a negative effect on the cooling load [4]. The authors studied on the heating properties of LED lighting and establish a management strategy to exploit these properties to reduce the energy used for heating and cooling of buildings.

Internal heat gains from electrical equipment, machines, computer and cooking is defined as miscellaneous heat gains. Using high efficiency electrical equipment helps to decrease cooling load of the building.

Many authors studied to decrease the cooling load of the buildings and carbon emission [5]. Jenkins [6] stated that reduction in the cooling load and carbon emissions could be satisfied by the decrease of internal load with the help of 'make air tight and ventilate right' approach. Using fluorescent lamp instead of tungsten lamp is one of the ways of reducing lighting loads.

The aim of this paper is to show the effect of the internal heat gains on the cooling load of the three adults' house. DesignBuilder v4 software was used to calculate the internal loads. In the study, calibration data for simulation program was taken from data loggers. Moreover, a time schedule for operation time and occupancy was prepared to get more accurate results.

This paper was recommended for publication in revised form by Regional Editor Tolga Taner

${ }^{1 *}$ Energy Engineering Programme, Izmir Institute of Technology, Izmir, Turkey

${ }^{2}$ Mechanical Engineering Department, Izmir Institute of Technology, Izmir, Turkey

${ }^{3}$ Department of Architecture, Izmir Institute of Technology, Izmir, Turkey

*E-mail address: turgaycoskun@iyte.edu.tr 


\section{METHODOLOGY}

The case building was chosen in Izmir/Turkey to collect data for the cooling load calculation. Izmir, situated on the west cost of Turkey (latitude $38^{\circ} 25 \mathrm{~N}$, longitude $27^{\circ} 08 \mathrm{E}$ ), has a typical Mediterranean climate which is characterized as temperate-humid. The minimum average temperatures during winter vary between 6 and $8{ }^{\circ} \mathrm{C}$. Monthly mean temperatures, however, during summer (May-October) are almost $25^{\circ} \mathrm{C}$ or higher [7].

The case house is on the third floor of the four storey apartment. It is conjugated with two buildings from northern and southern facades. There is another building in the western facing of the flat and the distance between them is approximately four meters. A high school which is named as Inönü Anadolu High School is located ten meters distance from the eastern facing of the building and there is a road between them. There are no green areas around the building. Location of the building was drawn by using DraftSight V1R5 (Fig. 1).

As it seen from the Fig. 2, the house has three rooms, a living room, a kitchen, a bathroom and a balcony. Two facades (east and west) of the building take sunlight directly. Considering this, two data loggers were used to measure temperature of the flat. One of them was installed inside of the eastern wall of the living room and other one was installed the eastern balcony.

The place of the data loggers are shown in the Fig. 2. The components of the building and material properties of them are needed to be defined exactly to calculate the cooling load correctly.

Material properties are important to calculate heat transfer between the two different zones. The U values of the components of the case house are shown in Table 1.

The cooling load of the building was calculated by using simulation program. Also two data logger were put inside and outside of the living room to measure temperature and humidity of the building.

The model house was drawn in building format while other houses and surrounding buildings were drawn as component block. In Fig.3, dark red colors show the adiabatic components.

All of the component blocks were selected as adiabatic to prevent heat transfer between the case house and others.

Also, the heat transfer between Zone 1 and other zones was prevented by selecting the walls as adiabatic.

There is no central heating system for the case house. Only two zones (dining room and bedroom) are heated by using electrical heater.

An activity list, that includes occupancy time, operation time of the equipment, lighting, the opening time of the windows and doors, was prepared to create correct time schedule for all scenarios. Cooling load of the house was calculated in different cases. In first case, lighting devices were cancelled to see the effect of lighting on the cooling load. In other cases, same process was repeated for electrical equipment and occupants to see the effects on the cooling load. In last cases, all of them were cancelled and cooling load was calculated.

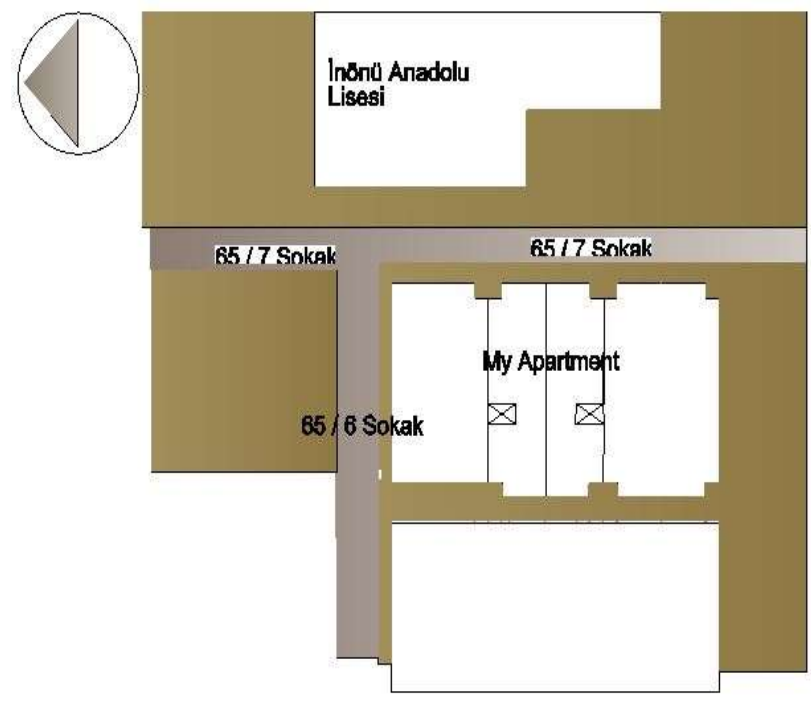

Figure 1. Cad drawing of the building 


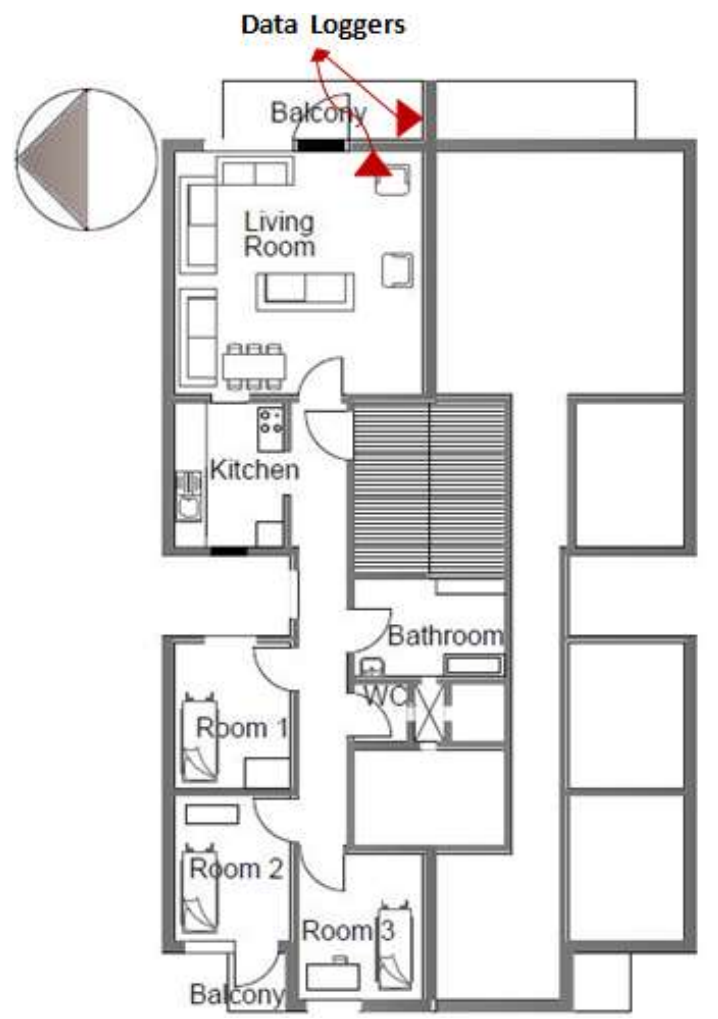

Figure 2. CAD drawing of the house plan

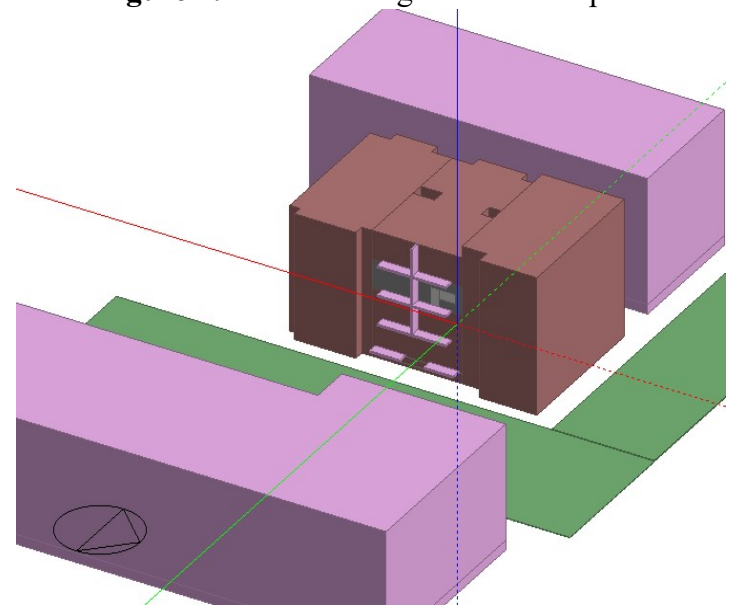

Figure 3. DesignBuilder drawing of the building

Table 1. Overall heat transfer coefficient of the building components

\begin{tabular}{|l|c|c|c|c|c|}
\hline Component & $\begin{array}{c}\text { External } \\
\text { Wall }\end{array}$ & $\begin{array}{c}\text { Internal } \\
\text { Wall }\end{array}$ & Floor & Ceiling & Glazing \\
\hline $\mathbf{U}\left(\mathbf{W} / \mathbf{m}^{\mathbf{2}} \mathbf{K}\right)$ & 1.797 & 2.033 & 2.724 & 2.724 & 2.716 \\
\hline
\end{tabular}




\section{RESULTS AND DISCUSSION}

Temperature of the house was observed during three weeks (1st April to 22th April) by using data loggers. The calibration of the simulation software was made according to the measurements. The graph of the calibration is shown in Fig. 5.

The calibration between the hobo temperature and simulation temperature was carried out by changing the air tightness and overall heat transfer coefficients of the external wall. Energy consumption of the building was calculated annually after the calibration process was completed.

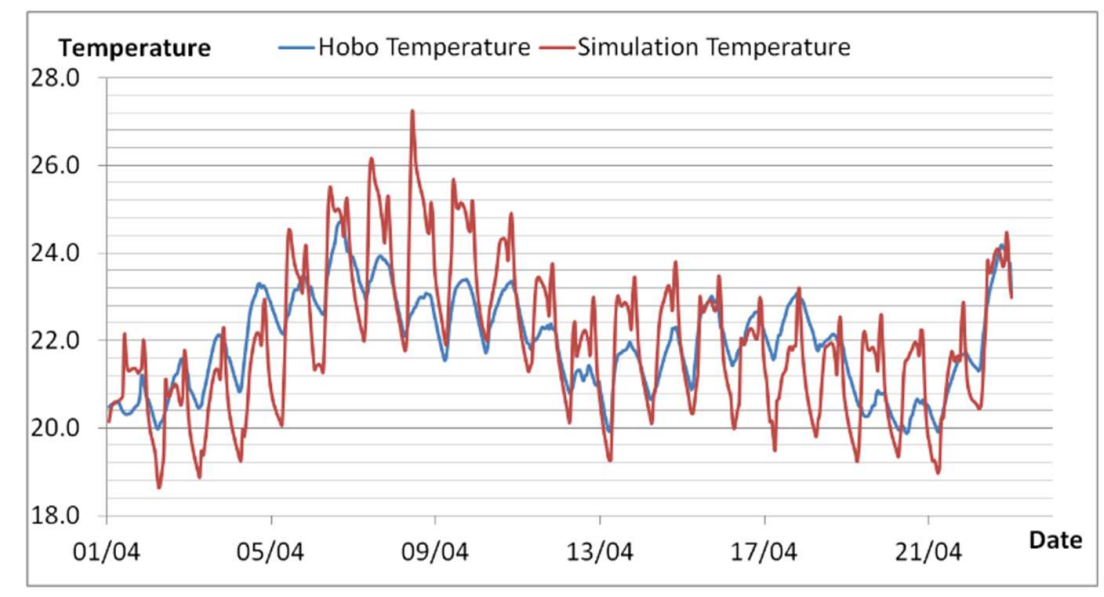

Figure 5. Calibration of the temperature

Table 2. Annual energy consumption

\begin{tabular}{|c|c|c|}
\hline $\begin{array}{c}\text { Annual Energy } \\
\text { Consumption (kWh) }\end{array}$ & Area(m $\left.\mathbf{m}^{\mathbf{2}}\right)$ & $\begin{array}{c}\text { Consumption per } \\
\text { area }\left(\mathbf{k W h} / \mathbf{m}^{\mathbf{2}}\right)\end{array}$ \\
\hline 3400.97 & 75.78 & 44.88 \\
\hline
\end{tabular}

Table 3. Distribution of energy consumption between the systems

\begin{tabular}{|c|c|c|c|c|}
\hline & Heating & Lighting & Equipment & $\begin{array}{c}\text { Water } \\
\text { (DHW) }\end{array}$ \\
\hline $\begin{array}{c}\text { Energy } \\
\text { Consumption } \\
\text { (kWh) }\end{array}$ & 1514.31 & 80.93 & 1607.3 & 198.43 \\
\hline
\end{tabular}

Table 4. Cooling load of the house for a summer day

\begin{tabular}{|c|c|c|c|}
\hline Case & $\begin{array}{c}\text { Design } \\
\text { Capacity } \\
(\mathbf{k W})\end{array}$ & $\begin{array}{c}\text { Total } \\
\text { Cooling } \\
\text { Load }(\mathbf{k W})\end{array}$ & $\begin{array}{c}\text { Cooling } \\
\text { Load }(\%)\end{array}$ \\
\hline Total & 12.74 & 11.08 & 100 \\
\hline No lighting & 12.70 & 11.04 & 0.36 \\
\hline No occupancy & 12.64 & 10.99 & 0.81 \\
\hline No equipment & 12.66 & 11.01 & 0.63 \\
\hline $\begin{array}{c}\text { No Eq., Occ. \& } \\
\text { Light. }\end{array}$ & 12.55 & 10.91 & 1.53 \\
\hline
\end{tabular}


As shown in Table 2, the annual energy consumption of the case house was measured as $3400 \mathrm{kWh}$.

The distribution of energy consumption between the systems is shown in Table 3 . The highest energy consumption is for the equipment. In contrast, the lowest energy consumption is for lighting.

Total cooling load of the building when all of the sources are included was calculated for a summer day (Table 4).

Total cooling load of the flat was determined as $11.08 \mathrm{~kW}$ for summer day. $0.36 \%$ of the cooling load was due to lighting devices. The percentage of electrical equipment in the cooling load of building was found as $0.63 \%$. The occupants supply more heat than equipment and lighting devices. The percentage of occupants in the cooling load of building was calculated as 0.81 . When all of the internal heat gains sources were cancelled, the cooling load of the building reduced $0.17 \mathrm{~kW}(1.53 \%)$.

\section{CONCLUSION}

This paper looks at the response of the cooling load for a case building located in İzmir/Turkey when internal changes are made. The calculation of energy consumption and cooling load of the case house was determined by using DesignBuilder software. All necessary parameters like geometry of the house, materials, detailed time schedule for occupancy and operation time, lighting were specified and imported the simulation software to make correct calculation. The result shows that most of the cooling load in the flat is due to equipment and heating system. It is suggested that using more efficient technologies (such as LED lighting and energy efficient appliances) makes large reduction to the cooling load.

Also, the studies shows that in building simulation, accurate schedules for occupancy, equipment and lighting systems are important to gather correct results from dynamic simulation programs.

\section{NOMENCLATURE}

U Heat transfer coefficient, $\mathrm{W} / \mathrm{m}^{2} \mathrm{~K}$

LED Light emitted diode

\section{REFERENCES}

[1] P. Lubina, M. B. Nantka, Internal heat gains in relation to the dynamics of the buildings heat requirements, Architecture Civil Engineering Environment, 1 (2009) 137-142.

[2] T. Al-Shemmeri, Building's Heat Gains, 2011, Available

from:http://www.wiley.com/legacy/wileychi/al_shemmeri/supp/powerpoints/chapter_5.pdf (retrieved 25.04.2014)

[3] C. Martani, D. Lee, P. Robinson, R. Britter, C. Ratti, ENERNET: Studying the dynamic relationship between building occupancy and energy consumption, Energy and Buildings, 47 (2012), 584-591.

[4] B. L. Ahn, C.Y. Jang, S. B. Leigh, S. Yoo, H. Jeong, Effect of LED lighting on the cooling and heating loads in office buildings, Applied Energy, 113 (2014) 1484-1489.

[5] Y. Anand, S. Anand, A. Gupta, S. K. Tyagi, Building envelope performance with different insulating materialsan exergy approach, Journal of Thermal Engineering, 6 (2015) 433-439.

[6] D.P. Jenkins, The Importance of office internal heat gains in reducing cooling loads in a changing climate, International Journal of Low-Carbon Technologies, 4 (2009) 134-140.

[7] C. Turhan, T. Kazanasmaz, İ.E. Uygun, K.E. Ekmen, G.G. Akkurt, Comparative study of a building energy performance software (KEP-IYTE-ESS) and ANN-based building heat load estimation, Energy and Buildings, 80 (2014) 115-125.

[8] A.C. Menezesa, A. Crippsa, R.A. Buswellb, J. Wrightb, D. Bouchlaghem, Estimating the energy consumption and power demand of small power equipment in office buildings, Energy and Buildings, 75 (2014) 199-209.

[9] DesignBuilder, v4, http://www.designbuilder.co.uk/

[10] DraftSight,V1R5,https://www.3ds.com/products-services/draftsight-cad-software/ 